\title{
Analysis of bioavailable toluene by using recombinant luminescent bacterial biosensors with different promoters
}

\author{
Guey-Horng Wang ${ }^{1}$, Teh-Hua Tsai ${ }^{2}$, Chun-Chi Kuil ${ }^{3}$, Chiu-Yu Cheng ${ }^{3}$, Tzu-Ling Huang ${ }^{3}$ and Ying-Chien Chung $^{3^{*}}$ (D)
}

\begin{abstract}
In this study, we constructed recombinant luminescent Escherichia coli with T7, T3, and SP6 promoters inserted between tol and lux genes as toluene biosensors and evaluated their sensitivity, selectivity, and specificity for measuring bioavailable toluene in groundwater and river water. The luminescence intensity of each biosensor depended on temperature, incubation time, ionic strength, and concentrations of toluene and coexisting organic compounds. Toluene induced the highest luminescence intensity in recombinant lux-expressing E. coli with the T7 promoter [T7-lux-E. coli, limit of detection $(\mathrm{LOD})=0.05 \mu \mathrm{M}]$, followed by that in E. coli with the T3 promoter (T3-luxE. coli, LOD $=0.2 \mu \mathrm{M}$ ) and SP6 promoter (SP6-lux-E. coli, LOD $=0.5 \mu \mathrm{M}$ ). Luminescence may have been synergistically or antagonistically affected by coexisting organic compounds other than toluene; nevertheless, low concentrations of benzoate and toluene analogs had no such effect. In reproducibility experiments, the biosensors had low relative standard deviation (4.3-5.8\%). SP6-lux-E. coli demonstrated high adaptability to environmental interference. T7-lux-E. coli biosensor — with low LOD, wide measurement range $(0.05-500 \mu \mathrm{M})$, and acceptable deviation (- 14.3 to 9.1\%) is an efficient toluene biosensor. This is the first study evaluating recombinant lux E. coli with different promoters for their potential application in toluene measurement in actual water bodies.
\end{abstract}

Keywords: Biosensor, Groundwater, Promoter, Toluene

\section{Introduction}

The large-scale consumption of petroleum-derived fuels has led to groundwater and soil contamination through their leakage from fuel tanks and pipelines. Because of its moderate solubility in water and toxicity, toluene is a petrochemical contaminant of particular concern [1]. Even at low concentrations, toluene can be carcinogenic, can exhibit mutagenic properties, and can damage the kidney, liver, and central nervous system [2]. In Taiwan, environmental agencies have set acceptable limits for toluene in drinking water and groundwater at considerably low levels $(7.6-10.9 \mu \mathrm{M})[3,4]$. In addition, toluene

\footnotetext{
* Correspondence: ycchung@cc.cust.edu.tw

${ }^{3}$ Department of Biological Science and Technology, China University of Science and Technology, Taipei 11581, Taiwan

Full list of author information is available at the end of the article
}

measurement is paramount for the monitoring and clean-up of contaminated groundwater and surface water. Thus, the need for sensitive toluene detection is high, but its design is challenging. In particular, toluene is found in various water bodies, including rivers, as well as coastal water and groundwater; even drinking water contains toluene at trace concentrations $(\mu \mathrm{M})[1]$.

Conventional analytical techniques, such as gas chromatography (GC) and high-performance liquid chromatography, are sensitive and reliable for toluene detection but are time-consuming, expensive, and laboratorybound, and they require large equipment and specialized training $[5,6]$. By contrast, biological methods can be useful alternatives for organics detection because they are low cost, easy to use, portable, small, and highly specific and can detect bioavailability [7-9]. Of the 
biological methods, biosensors are suitable for application as environmental sensors, even for on-field measurements.

Over the last 20 years, biosensors have been developed and are widely used as simple and practical approaches for the sensitive and specific detection of various compounds, including organic compounds (pesticides and chlorophenol), heavy metals (mercury, zinc, and cadmium), and some inorganic compounds [9-11]. Wholecell biosensors rely on gene expression analysis: transcriptional fusions between a promoter and a reporter gene are created, and the extent of reporter gene expression is used to indicate the pollutant concentration [12]. Several engineered biosensors have specifically discriminated between alkyl-substituted benzene derivatives in water samples [13].

A biosensor of this type can be genetically engineered by placing a reporter gene, such as lacZ, gfp, luc, or lux, under the control of a transcriptional activator [11, 14]. Under appropriate conditions (e.g., in the presence of specific pollutant), the biosensor can produce a detectable signal (color or luminescence) that is directly correlated to the pollutant concentration [12, 15]. This property can aid in directly correlating the toluene concentration with the reporter enzyme activity. Various biosensors for benzene, toluene, ethylbenzene, and xylene detection have been developed on the basis of the tol plasmid of Pseudomonas putida mt-2 [16, 17]. In particular, bioluminescence is highly applicable as a reporter for pollutant detection because its instrumentation is sensitive for detecting light production [18]. However, Escherichia coli cells harboring this plasmid often express various response levels when constructed with different reporter genes or promoters that can lead to a range of linear measurement ranges and limits of detection (LODs) [19]. For instance, among induction-based biosensors, luc-, lux-, and aequorinbased biosensors have the LODs of $11,7.5$, and $1 \mu \mathrm{M}$, respectively [20-22]. Of the reporter genes, lux has acceptable sensitivity for signal production [18]. Measurement of toluene at very low concentration levels is a main goal of current environmental research; therefore, for the practical application of these biosensors, efforts toward overcoming the aforementioned limitations are warranted [23]. Rational selection of a suitable promoter or reporter gene is essential for increasing the sensitivity, signal intensity, and response speed of whole-cell biosensors.

SP6, T3, and T7 promoters, which are widely used for in vitro transcription, have similar but distinct promoter specificities [24]. They are classified as strong or weak promoters according to their RNA polymerase affinities. T7 is a strong promoter that maintains gene expression tuned to the highest level, thus potentially producing high signal intensity [25]. By contrast, weaker promoter (T3 and SP6) may adapt environmental variation, which produces different signal characteristics [26]. Thus, the linear measurement ranges and LODs of whole-cell biosensors would be expanded or improved if recombinant luminescent bacteria with suitable promoters are constructed.

In this study, we applied this strategy to construct recombinant E. coli strains carrying the tol plasmid from $P$. putida and including various promoters (T7, T3, or SP6) controlling lux expression. By optimizing the promoter and regulating the $l u x$ expression level in E. coli, the recombinant luminescent biosensors could detect bioavailable toluene under different environmental conditions.

\section{Results and discussion}

Comparison of time-dependent induction of our three recombinant luminescent $E$. coli strains with toluene

Figure 1 illustrates the construction of the three recombinant plasmids. According to the preliminary experiment, the logarithmic growth phases of the three recombinant E. coli strains occurred from 6 to $15 \mathrm{~h}$ of incubation, and the relationship between OD of bacterial growth and RLU (Relative Light Unit) emitted from the three recombinant $E$. coli strains was linear from 8 to 14 $\mathrm{h}$ of incubation. Accordingly, the inoculation time of the three recombinant $E$. coli strains for the subsequent experiment was set as $12 \mathrm{~h}$ after incubation. Figure 2 presents a comparison of the time-dependent induction of luminescence emitted from T3-lux-E. coli, SP6-lux-E. coli, and T7-lux-E. coli caused by different toluene concentrations. As shown in Fig. 2, the induction of luminescence caused by different toluene concentrations occurred time-dependently, regardless of the promoter type. The luminescence intensity continuously increased, leveled off, and then began to decrease considerably during incubation, all potentially due to the biochemical nature of the reporter gene $\operatorname{lux}$ [27].

The results demonstrated that luminescence was stable and the greatest at $2-2.5 \mathrm{~h}$ after incubation for T3-lux-E. coli and T7-lux-E. coli or 1-1.5 h after incubation for SP6-lux-E. coli. The time was equal to or shorter than that previously reported for the lux-based bioluminescent bioreporter P. putida TVA8 $(2 \mathrm{~h})$ and luminescence bacterial biosensors without the T7 promoter $(3 \mathrm{~h})$ for toluene measurement $[6,21]$. Therefore, on average, 20-min consecutive measurements were recorded when T3-lux-E. coli and T7-lux-E. coli were cultured for $2 \mathrm{~h}$ and when SP6-lux-E. coli was cultured for $1 \mathrm{~h}$. The maximum average luminescence induced by $200 \mu \mathrm{M}$ toluene for T3-lux-E. coli, SP6-lux-E. coli, and T7-lux-E. coli was $1020 \pm 20,510 \pm 10$, and $2120 \pm 60$ RLU, respectively. Moreover, at the same toluene 


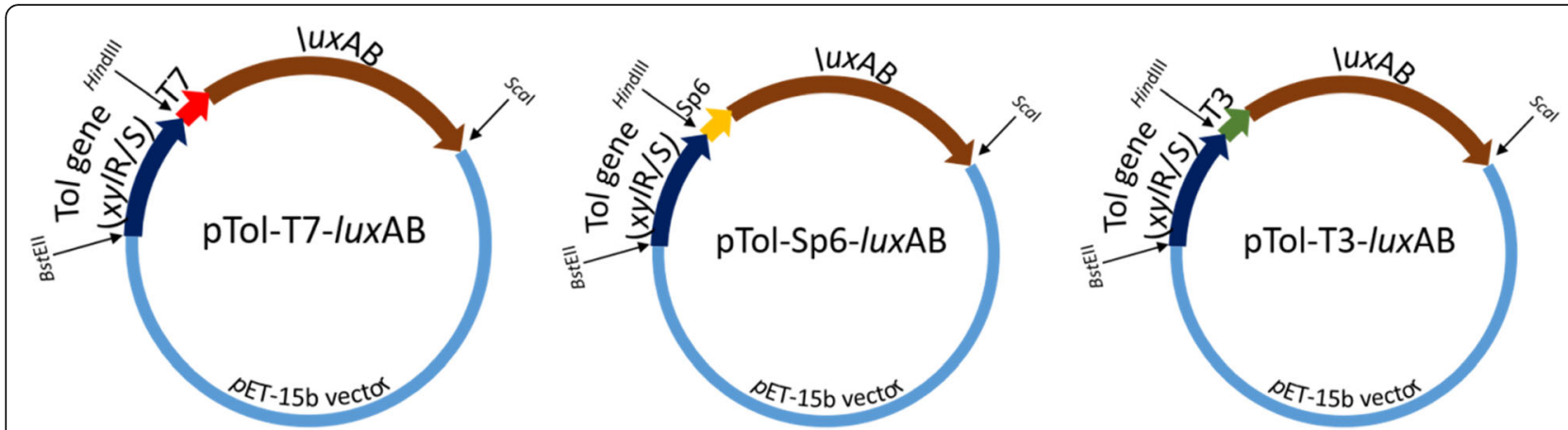

Fig. 1 Construction of pTOL-T3-lux, pTOL-SP6-lux and pTOL-T7-lux

concentration, the signal intensity of luminescence decreased as follows: T7-lux-E. coli $>$ T3-lux-E. coli $>$ SP6lux-E. coli. However, SP6-lux-E. coli had the shortest stable period for luminescence induction. Previous research demonstrated an increase in bioluminescence emission by fusing the T7 promoter to control expression of the lux operon [28].

\section{Effects of culture conditions on luminescence}

The effects of incubation temperature and ionic strength on the induction of luminescence biosensors for toluene were evaluated according to practical considerations. Figure 3a illustrates the effects of incubation temperature on the luminescence induced by $100 \mu \mathrm{M}$ toluene for T7-lux-E. coli. The experimental results demonstrated the optimal temperature range of luminescence for T7-lux-E. coli to be $30-37^{\circ} \mathrm{C}$, with nonsignificant differences $(p>0.05)$. Similar results were observed for T3-luxE. coli and SP6-lux-E. coli. Moreover, luminescences of the three recombinant E. coli strains at 20 and $40{ }^{\circ} \mathrm{C}$ were $12.1-15.3 \%$ and $24.4-26.8 \%$ lower than those at $37^{\circ} \mathrm{C}$, respectively. The effect of high temperature on the luminescence of the recombinant E. coli strain was more noticeable, a result attributable to the physiological characteristics of the E. coli [29]. Thus, subsequent experiments were performed at $37^{\circ} \mathrm{C}$ for all three recombinant E. coli strains.

Figure $3 \mathrm{~b}$ shows the effects of ionic strength on the luminescence of the recombinant $E$. coli with the T3, SP6, or T7 promoter that were induced by $100 \mu \mathrm{M}$ toluene. The results demonstrated almost no effect of different ionic strengths on the luminescence for SP6-lux-E. coli, but the ionic strength had greater effects on that of T7lux-E. coli. When the ionic strength was $0.55 \mathrm{M}$, the luminescence of T7-lux-E. coli decreased by $12.5 \% \pm 0.6 \%$. This inconsistency among the recombinant $E$. coli with different promoters was presumed to be related to promoter structure and composition, which determine the strength of various types of promoter-target DNA bonds [30]. Additional experiments to investigate these differences are planned. In general, the ranges of ionic strengths of groundwater, river water, seawater, and polluted water are $0.01-0.02 \mathrm{M}, 10^{-3}-10^{-2} \mathrm{M}, 0.45-0.55 \mathrm{M}$, and $>10^{-2} \mathrm{M}$, respectively. Thus, SP6-lux-E. coli is suitable for application in various water environments (groundwater, river water, and seawater), whereas T7lux $E$. coli is suitable for use in low ionic strength environments.
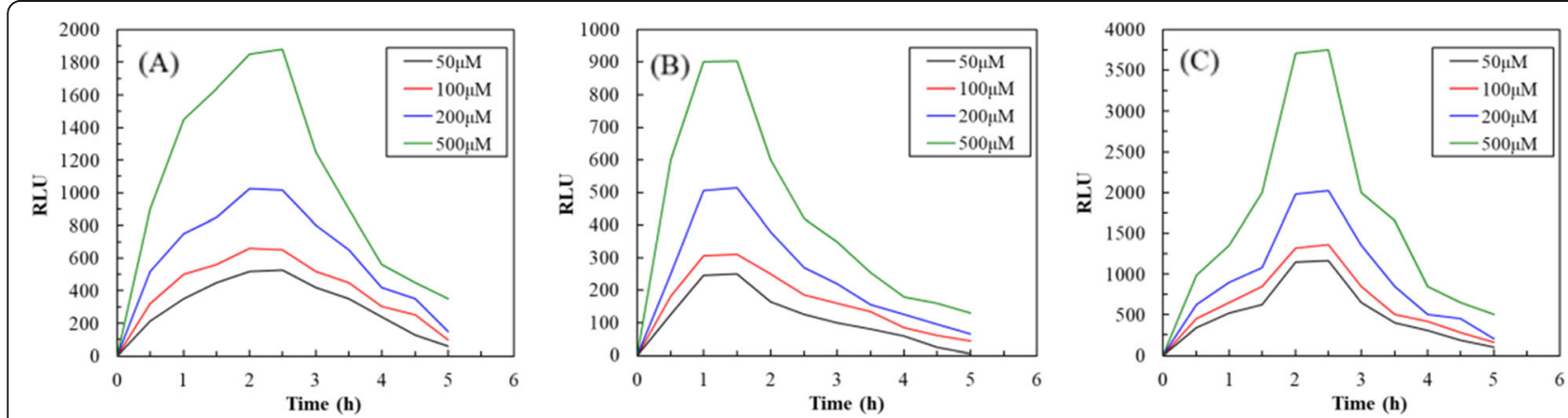

Fig. 2 Comparison of time-dependent induction of luminescence from (a) T3-lux-E. coli, (b) SP6-lux-E. coli, and (c) T7-lux-E. coli; initial cell concentration: $5 \times 10^{7} \mathrm{cfu} / \mathrm{mL}$, culture media: TMM with different toluene concentration, operational conditions: $37^{\circ} \mathrm{C}$ and $200 \mathrm{rpm}$ 

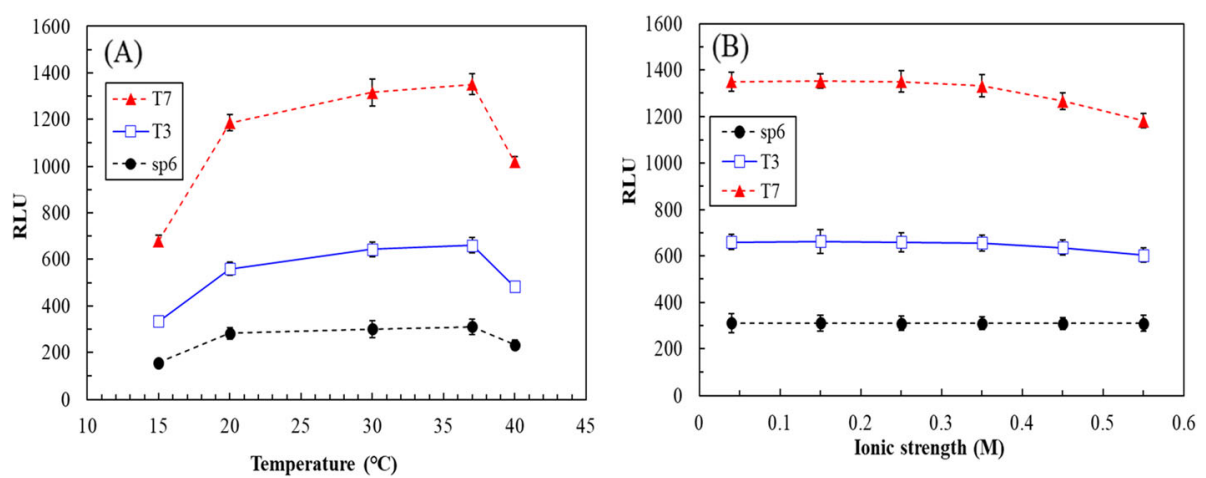

Fig. 3 a Effects of incubation temperature on luminescence of T7-lux-E. coli induced by $100 \mu \mathrm{M}$ toluene for $2 \mathrm{~h}$. $\mathbf{b}$ Effects of ionic strength on the luminescence of T3-lux-E. coli, SP6-lux-E. coli and T7-lux-E. coli induced by $100 \mu \mathrm{M}$ toluene for $2 \mathrm{~h}$ (T3-lux-E. coli and T7-lux-E. coli) or $1 \mathrm{~h}$ (SP6-lux-E. coli)

Effects of coexisting carbon sources, intermediates, and toluene analogs on luminescence

The $x y l$ genes of the Pseudomonas putida TOL plasmid encode the genetic information required for the degradation of toluene and related aromatic compounds. The $x y l R$ and $x y l S$ genes of the $x y l$ structural genes encode the regulatory proteins of the catabolic operons, whereas the XylR protein is the master regulator of TOL plasmid catabolic operons for the metabolism of toluene [31]. Transcription of the operon is positively regulated by the XylR/XylS protein activated by toluene, xylenes, or their alcohol catabolic products [32]. Figure 4a illustrates the effects of coexisting carbon sources at $100 \mu \mathrm{M}$ on the luminescence of T7-lux-E. coli and SP6-lux-E. coli. The tested chemicals are considered potential inhibitors or activators (indirect or direct inducers) of $x y l S$ and $x y l R$ and may deviate significantly or have an additive effect in relation to theoretically expected effects, calculated on the basis of individual chemicals [12, 33, 34]. The current results demonstrated that the coexistence of
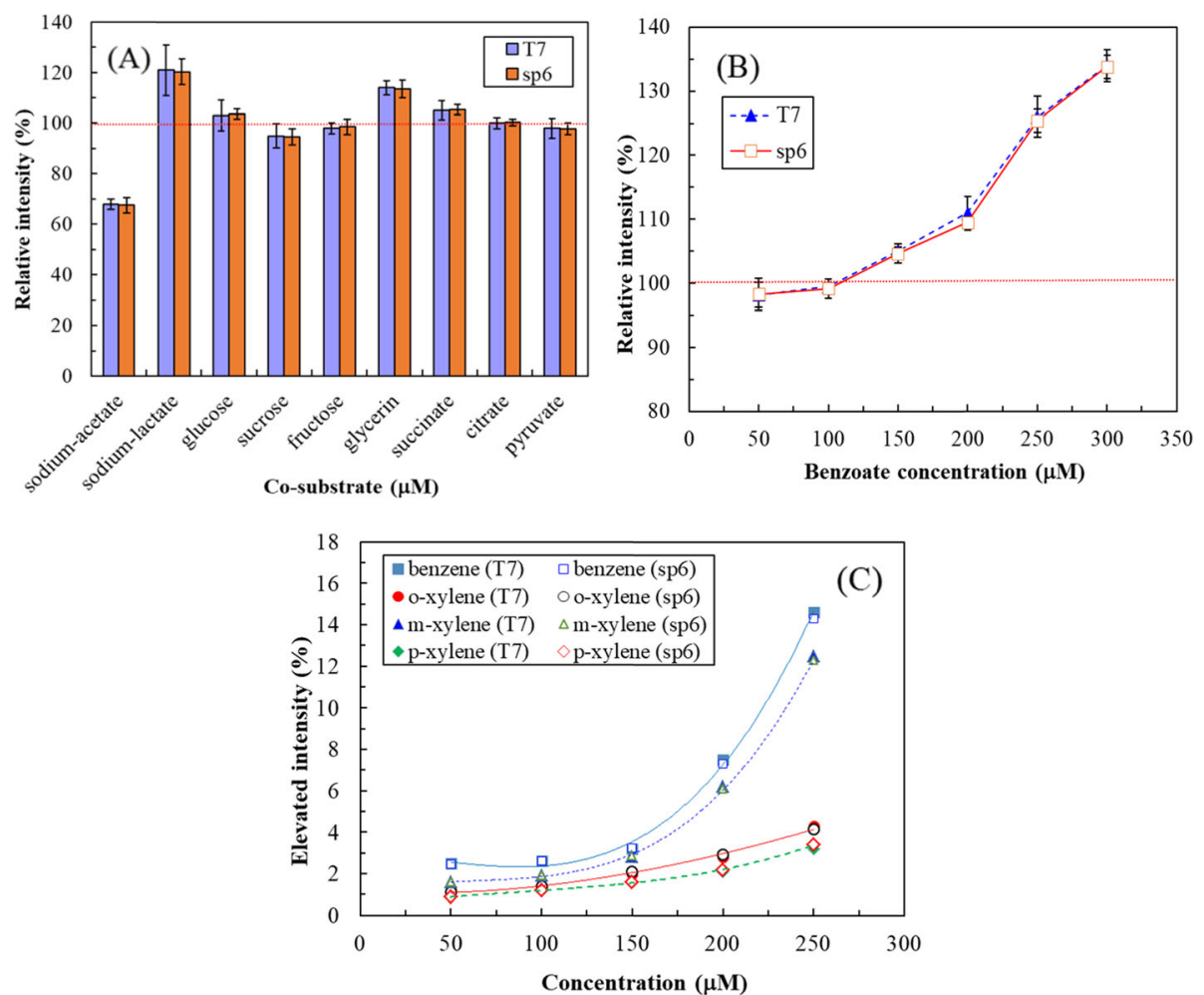

Fig. 4 Effects of (a) coexisting carbon sources $(100 \mu \mathrm{M})$, (b) benzoate, and (c) toluene analogs and their concentrations on luminescence of T7lux-E. coli and SP6-lux-E. coli induced by $100 \mu \mathrm{M}$ toluene for $2 \mathrm{~h}$ or $1 \mathrm{~h}$ 
lactate or glycerin with toluene induced greater luminescence than did toluene alone. Lactate at $100 \mu \mathrm{M}$ increased luminescence by $21 \% \pm 8.6 \%$ for T7-lux-E. coli and $20.3 \% \pm 5.1 \%$ for SP6-lux-E. coli, while glycerin increased by $14 \% \pm 1.8 \%$ for T7-lux-E. coli and $13.5 \% \pm$ $3.5 \%$ for SP6-lux-E. coli, respectively. The increased luminescence disappeared when the concentrations were below $70 \mu \mathrm{M}$ (lactate) or $85 \mu \mathrm{M}$ (glycerin). By contrast, the coexistence of acetate with toluene induced lower luminescence than did toluene alone; luminescence decreased by $32 \% \pm 1.5 \%$ for T7-lux-E. coli and $32.5 \% \pm$ $2.9 \%$ for SP6-lux-E. coli. However, for other chemicals, the coexistence had negligible effect on the detection of toluene by T7-lux-E. coli and SP6-lux-E. coli.

Figure $4 \mathrm{~b}$ illustrates the effects of the benzoate concentration on the luminescence of T7-lux-E. coli and SP6-lux-E. coli. Benzoate is the most important metabolite produced during toluene biodegradation [35], which may affect $X y l S$ expression [33]; thus, we evaluated the effect of the benzoate concentration on the luminescence of T7-lux-E. coli and SP6-lux-E. coli. The results demonstrated that a high benzoate concentration could induce higher luminescence than did toluene alone, as detected using T7-lux-E. coli and SP6-lux-E. coli. Although $50-150 \mu \mathrm{M}$ benzoate did not affect luminescence, $250-300 \mu \mathrm{M}$ benzoate increased luminescence by $26 \% \pm 3.5 \%$ for T7-lux-E. coli $(25.4 \% \pm 1.8 \%$ for SP6-luxE. coli) and $34 \% \pm 2.8 \%$ for T7-lux-E. coli $(33.8 \% \pm 1.8 \%$ for SP6-lux-E. coli), respectively. In other words, the effect of low concentrations of benzoate on luminescence was limited when toluene was detected by T7-lux-E. coli or SP6-lux-E. coli.

Figure 4c illustrates the effects of toluene analogs and their concentrations on the luminescence of T7-lux-E. coli and SP6-lux-E. coli. The results demonstrated that the various concentrations of $o$-xylene and $p$-xylene had negligible effects on toluene detection by the recombinant $E$. coli biosensor; moreover, even when $250 \mu \mathrm{M} o$-xylene was used, only $4.15-4.30 \%$ increase in luminescence was observed. However, $250 \mu \mathrm{M} m$-xylene and $250 \mu \mathrm{M}$ benzene induced T7-lux-E. coli or SP6-lux-E. coli to produce relatively high luminescence $(12.3-12.5 \%$ and $14.3-14.6 \%$, respectively). By contrast, the effect of the toluene analog concentration of $\leq 200 \mu \mathrm{M}$ on toluene detection was limited $(<8 \%)$. The effect of the synergistic mode was far lower than that observed in the $P$. putida mt-2 KG1206 biosensor [12].

Taken together, these results illustrate that our recombinant luminescent biosensor possesses high selectivity and specificity when detecting a group of analytes with similar chemical structures. Because the included chemicals mainly affect the regulatory genes $x y l S$ or $x y l R$, but not the T3, SP6, or T7 promoter, their effects on the magnitude of luminescence among all three recombinant
E. coli biosensors were similar [12]. Figure 4 exemplifies the cases of T7-lux-E. coli and SP6-lux-E. coli.

\section{Relationship of toluene concentration with luminescence} The function of these promoters (T7, T3, SP6) is to make the downstream reporter gene (lux) more strongly expressed. Therefore, $x y l R$ is first induced in the presence of toluene and activates gene expression, then the promoters and reporter gene $(l u x)$ follow. Under optimal operating conditions, we determined the relationships between the toluene concentration and the luminescence of the three recombinant $E$. coli strains. Two sets of linear relationships were observed between the toluene concentration and luminescence at different concentration ranges. Figure $5 \mathrm{a}$ presents a set of regression equations for the toluene concentration and the luminescence of T7-lux-E. coli, T3-lux-E. coli, and SP6$l u x-E$. coli when the toluene concentration was 10
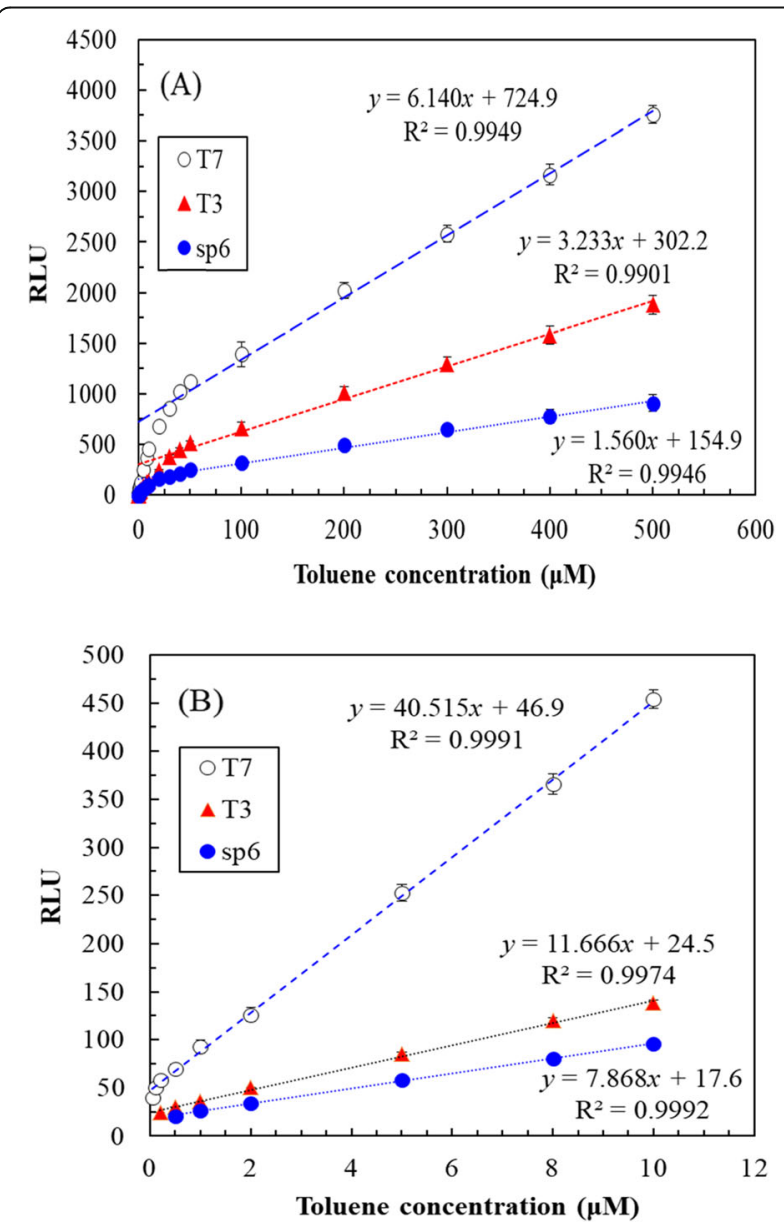

Fig. 5 Relationship between toluene concentration [(a) 0.01-500 and (b) $0.05-10 \mu \mathrm{M}$ ] and luminescence of recombinant $E$. coli with different promoters (initial cell concentration: $5 \times 10^{7} \mathrm{cfu} / \mathrm{mL}$, culture media: TMM, operational condition: $37^{\circ} \mathrm{C}$ and $200 \mathrm{rpm}$, incubation time: $2 \mathrm{~h}$ for T3/T7-Iux-E. coli and $1 \mathrm{~h}$ for SP6-lux-E. coli) 
$500 \mu \mathrm{M}: \quad y=6.140 x+724.9, \quad y=3.233 x+302.2$, and $y=$ $1.560 x+154.9$, respectively. Figure $5 b$ presents another set regression equations for T7-lux-E. coli, T3-lux-E. coli, and SP6-lux-E. coli when the toluene concentration was $\leq 10 \mu \mathrm{M}: y=40.515 x+46.9, y=11.666 x+24.5$, and $y=7.868 x+17.6$, respectively. The coefficients of determination for these equations was high (>0.99), indicating their reliability. The concentration-dependent differences in these linear relationships may have been due to differences in promoter characteristics [36]. Moreover, for T7-lux-E. coli, T3-lux-E. coli, and SP6lux $-E$. coli, the LODs for toluene were 0.05, 0.2, and $0.5 \mu \mathrm{M}$, respectively. Therefore, T7-lux-E. coli was the most sensitive. Willardson et al. (1998) constructed a bacterial biosensor with the reporter gene luc, Casavant et al. (2003) constructed a site-specific recombinationbased biosensor with tbuA1UBVA2C promoter, Li et al. (2008) constructed a lux-based bacterial biosensor, Zeinoddini et al. (2010) constructed a aequorin-based $E$. coli biosensor, Zhong et al. (2011) constructed a monooxygenase biosensor, and Ray et al. (2018) constructed a protein-based biosensor; their LODs for toluene were $10,0.2,7.5,1,3$, and $3.3 \mu \mathrm{M}$, respectively [13, 20-22, 37, 38]. Compared with the aforementioned biosystems, T7lux-E. coli has lower LOD $(0.05 \mu \mathrm{M})$, indicating acceptable sensitivity. To develop a biosensor for detecting toluene, reporter genes such as $l u c$, lux, and aequorin were often constructed downstream of the degradation gene. However, these biosensors could not measure trace levels of toluene contamination in wastewater. To improve the LOD, a promoter (T7, T3, or SP6) was inserted between the degradation gene and reporter gene. To our knowledge, little has been reported on applying this strategy to regulate the expression of the reporter gene and improve the LOD of a biosensor for toluene. In conclusion, the novel plasmid or biosensor with low LOD constructed here exhibited high potential for measuring bioavailable toluene.

Hence, on the basis of the aforementioned reliable equations or the calibration curve for $0.05-10$ or $10-$ $500 \mu \mathrm{M}$ toluene, the toluene concentration in the water samples can be rapidly determined. In addition, the broad detection ranges of T7-lux-E. coli indicate that it is a practical toluene measurement tool.

\section{Reproducibility}

To evaluate the reproducibility of the biosensors for detecting toluene, T7-lux-E. coli, T3-lux-E. coli, and SP6lux-E. coli were tested under identical conditions by using TMM containing $10 \mu \mathrm{M}$ toluene. Relative standard deviation (RSD) for T7-lux-E. coli, T3-lux-E. coli, and SP6-lux-E. coli was 4.3, 5.1, and 5.8\%, respectively ( $n=$ 10). Batch-to-batch variation was also tested by comparing the luminescence from the five sets, which was tested using TMM containing $10 \mu \mathrm{M}$ toluene, and the RSD for T7-lux-E. coli, T3-lux-E. coli, and SP6-lux-E. coli was $6.2,6.5$, and $9.4 \%$, respectively. These results are comparable to the reproducibility reported for two induction-based toluene biosensors: $\mathrm{RSD}=9.5 \%$ for $n=3$ (with $21.7 \mu \mathrm{M}$ toluene) and $\mathrm{RSD}=7.4 \%$ for $n=8$ (with $92 \mu \mathrm{M}$ toluene) $[38,39]$. Thus, our recombinant luminescent $E$. coli biosensors demonstrated operational stability. Similar results were obtained when these biosensors were applied for measuring $10 \mu \mathrm{M}$ toluene after a 3-month cryogenic storage period.

Toluene measurement in groundwater and river water by using our three recombinant luminescent $E$. coli biosensors

Most luminescent biosensors have been applied for measuring toluene availability in artificial wastewater, but few have been applied in actual wastewater. Table 1 summarizes the measured toluene concentrations in seven groundwater samples and three river water samples using our three recombinant luminescent $E$. coli biosensors and the standard GC-MS method. The results demonstrated that the toluene concentration determined using our biosensors and through GC-MS demonstrated excellent correlation $\left(r^{2}>0.998\right)$; moreover, the deviation between the toluene concentrations measured through GC-MS and those measured using T7-lux-E. coli, T3-lux-E. coli, and SP6-lux-E. coli was 14.3 to $9.1 \%,-10.7$ to $26.7 \%$, and -3.6 to $4.2 \%$, respectively. Considering the measurement ranges and accuracy, T7-lux-E. coli provided the accurate and reliable toluene measurement in these aqueous matrices. However, under appropriate toluene concentration ranges, SP6-lux-E. coli could be the best biosensor in terms of accuracy, and its genetic assembly is relatively less susceptible to environmental interference [26]. The measurement deviation of T7-lux-E. coli and SP6-lux-E. coli were comparable to that ( -16.7 to $7.5 \%$ ) of electrochemical inhibition bacterial sensor array for toluene detection [40]. Taken together, these results indicate that the developed recombinant luminescent bacterial biosensors can determine toluene concentration in different water bodies.

\section{Conclusions}

In this study, recombinant luminescent $E$. coli biosensors containing different promoters (T3, T7, and SP6) positioned before the reporter gene lux were developed for the accurate measurement of toluene concentrations in groundwater and river water. Of these biosensors, T7lux $-E$. coli was the most sensitive to toluene, with optimal LOD and widest measurement range for toluene concentrations. Moreover, SP6-lux-E. coli had the shortest reaction time and highest adaptability to 
Table 1 Toluene measurement from groundwater and river water by using the GC-MS method and biosensors

\begin{tabular}{|c|c|c|c|c|c|c|c|c|c|c|}
\hline \multirow[b]{2}{*}{ GC-MS } & \multicolumn{7}{|c|}{ Groundwater } & \multicolumn{3}{|c|}{ River water } \\
\hline & $0.15^{\mathrm{a}}$ & 0.56 & 1.20 & 9.5 & 5.6 & 15.6 & 0.082 & 0.12 & 20.6 & 31.5 \\
\hline T7-biosensor & $\begin{array}{l}0.16 \\
(6.7 \%)^{b}\end{array}$ & $0.61(8.9 \%)$ & $1.31(9.1 \%)$ & $\begin{array}{l}8.6 \\
(-9.5 \%)\end{array}$ & $\begin{array}{l}4.8 \\
(-14.3 \%)\end{array}$ & $\begin{array}{l}15.2 \\
(-2.6 \%)\end{array}$ & $\begin{array}{l}0.078 \\
(-4.9 \%)\end{array}$ & $\begin{array}{l}0.13 \\
(8.3 \%)\end{array}$ & $\begin{array}{l}18.5 \\
(-10.2 \%)\end{array}$ & $\begin{array}{l}30.6 \\
(-2.9 \%)\end{array}$ \\
\hline T3-biosensor & $N D^{c}$ & $\begin{array}{l}0.50 \\
(-10.7 \%)\end{array}$ & $\begin{array}{l}1.52 \\
(26.7 \%)\end{array}$ & $\begin{array}{l}10.1 \\
(6.3 \%)\end{array}$ & $6.1(8.9 \%)$ & $16.5(5.8 \%)$ & ND- & ND- & $21.8(5.8 \%)$ & $32.6(3.5 \%)$ \\
\hline $\begin{array}{l}\text { SP6- } \\
\text { biosensor }\end{array}$ & ND- & $0.54(-3.6 \%)$ & $1.25(4.2 \%)$ & $9.8(3.2 \%)$ & $5.8(3.6 \%)$ & $15.9(1.9 \%)$ & ND- & ND- & 20.9 (1.5\%) & $32.1(1.9 \%)$ \\
\hline
\end{tabular}

anit: $\mu \mathrm{M}$

${ }^{\mathrm{b}}$ Deviation compared with GC-MS-measured value

${ }^{\mathrm{c}} \mathrm{ND}$ meaning Not Detected, the value $<$ LOD

environmental interference but the poorest LOD. T7lux $-E$. coli exhibited competitive advantages over previously reported biosystems, particularly for optimal LOD and wide measurement range. According to the results of reproducibility experiments and the test on actual water samples, our lux-based biosensors exhibited the high operational stability (i.e., low RSD) and acceptable measurement deviation. In conclusion, our biosensors, particularly T7-lux-E. coli, are sensitive, reliable, specific, and stable systems for preliminary in-field detection of toluene in water samples.

\section{Materials and methods}

\section{Bacterial strains, gene cloning, and biosensor plasmid} construction

To clone the tol gene, partial tol in P. putida (ATCC 33015) was amplified using the primer set (forward $5^{\prime}$ GTTAACTGCATCCAGCCC-3', reverse 5'-CCGG GCGATGCCAACCC-3') through polymerase chain reaction (PCR). To clone T3-lux, SP6-lux, or T7-lux, lux in Vibrio vulnificus was amplified with the primer set for the corresponding genes (T7-lux, forward 5'- TAAT ACGACTCACTATAGGTCGACTTTATCGAGC CTGA-3' and reverse 5' -CAGCTGTTTTTGCTCCT-3'; T3-lux, forward 5' - ATTAACCCTCACTAAAGGTCGA CTTTATCGAGCCTGA-3' and reverse 5' -CAGCTGTT TTTGCTCCT-3'; SP6-lux, forward 5'-ATTTAGGTGA CACTATAGGTCGACTTTATCGAGCCTGA-3' and reverse 5 '-CAGCTGTTTTTGCTCCT-3') through PCR. All the resultant DNA fragments were inserted into the pET-15b vector plasmid (Promega, Madison, WI, USA). The recombinant plasmids were named pTOL, pT3-lux, pSP6-lux, and pT7-lux. In brief, the plasmids were then transferred to the expression host E. coli $\mathrm{DH} 5 \alpha$ and plated on Luria-Bertani (LB) agar plates. Then, isolated pTOL, pT3-lux, pSP6-lux, and pT7-lux plasmids were cut at cleavage sites using BstEII/HindIII and HindIII/ SanI. Next, pTOL-T3-lux, pTOL-SP6-lux, and pTOLT7-lux were constructed by ligating pTOL to pT3-lux, pSP6-lux, and pT7-lux fragments by using T4 DNA ligase (New England BioLabs, Beverly, MA, USA), respectively. The resulting plasmids were inserted into the $\mathrm{pET}$ -
$15 \mathrm{~b}$ vector plasmid. Next, the plasmids were transformed into $E$. coli $\mathrm{DH} 5 \alpha$ to create the corresponding whole-cell biosensors. All the restriction enzymes were purchased from New England BioLabs. Vector DNA was prepared using the QIAEX II gel extraction kit (Qiagen, Hilden, Germany).

\section{Bacterial growth}

E. coli with pTOL-T3-lux (T3-lux-E. coli), pTOL-SP6lux (SP6-lux-E. coli), and pTOL-T7-lux (T7-lux-E. coli) (all initial concentration $=2 \times 10^{5} \mathrm{cfu} / \mathrm{mL}$ ) were cultivated in $\mathrm{LB}$ broth containing $50 \mathrm{mg} / \mathrm{L}$ ampicillin at $37^{\circ} \mathrm{C}$ at $200 \mathrm{rpm}$ on an orbital shaker. Overnight cultures were then diluted 100-fold into toluene-mineral medium (TMM) containing $0.43 \mathrm{~g} / \mathrm{L} \mathrm{K}_{2} \mathrm{HPO}_{4}, 0.23 \mathrm{~g} / \mathrm{L} \mathrm{K \textrm {H } _ { 2 }} \mathrm{PO}_{4}$, $1 \mathrm{~g} / \mathrm{L} \quad \mathrm{NH}_{4} \mathrm{NO}_{3}, 0.2 \mathrm{~g} / \mathrm{L} \quad \mathrm{MgSO}_{4} 7 \mathrm{H}_{2} \mathrm{O}, 0.1 \mathrm{~g} / \mathrm{L} \quad \mathrm{CaCl}_{2}$, $0.05 \mathrm{mg} / \mathrm{L} \mathrm{Fe}_{2}\left(\mathrm{SO}_{4}\right)_{3}, 0.25 \mathrm{mg} / \mathrm{L} \mathrm{NaMoO}_{4} \cdot 2 \mathrm{H}_{2} \mathrm{O}, 50 \mathrm{mg} /$ $\mathrm{L}$ ampicillin, and a specific concentration of toluene (in this case: $10 \mathrm{mg} / \mathrm{L})$. The cultures were incubated at $37^{\circ} \mathrm{C}$ at $200 \mathrm{rpm}$ on an orbital shaker. The optical density (OD) measurements of the bacterial growth and the luminescence intensity released from recombinant $E$. coli were conducted at specific intervals. The OD of the cultures was measured at $600 \mathrm{~nm}$ on a UV-vis spectrophotometer (Shimadzu, Kyoto, Japan). The luminescence intensity [in relative light units (RLU)] was measured by adding $200 \mu \mathrm{L}$ of the culture to a 96-well microplate and then placing it under a microplate luminometer (Titertek-Berthold, Pforzheim, Germany). All chemicals used in the experiment were of analytical grade (purity > 99\%). Toluene was purchased from Sigma-Aldrich Corporation (St. Louis, MI, USA).

\section{Determination of optimum conditions}

After $12 \mathrm{~h}$ of cultivation in TMM, $1 \mathrm{~mL}$ of culture containing $5 \times 10^{7} \mathrm{cfu} / \mathrm{mL}$ T3-lux-E. coli, SP6-lux-E. coli, or T7-lux-E. coli was inoculated into $200 \mathrm{~mL}$ of TMM [with different final concentrations $(50-500 \mu \mathrm{M})$ of toluene] and incubated at $37^{\circ} \mathrm{C}$ on an orbital shaker (200 rpm) for $5 \mathrm{~h}$. The luminescence intensity was continuously measured until the luminescence intensity approached zero. The effects of temperature and ionic strength on 
bioluminescence emissions of the three recombinant $E$. coli strains were evaluated separately, and $100 \mu \mathrm{M}$ toluene was used as an inducer in TMM. During incubation, temperature $\left(15-40^{\circ} \mathrm{C}\right)$ was controlled using thermostat, and ionic strength $(0.04-0.55 \mathrm{M})$ was adjusted using aqueous $\mathrm{NaCl}$. After 2-h incubation for T3-lux-E. coli and T7-lux-E. coli and 1-h incubation for SP6-lux-E. coli, $200 \mu \mathrm{L}$ of the cultures were sampled, and the luminescence intensity (in RLU) of these biosensors was measured immediately. On average, 20-min consecutive measurements were recorded (i.e., one measurement every $0.5 \mathrm{~s}$ ).

Various carbon sources (i.e., acetate, lactate, glucose, sucrose, fructose, glycerin, succinate, citrate, and pyruvate) were added to TMM to evaluate their effects on bioluminescence emissions of the three recombinant $E$. coli strains. In medium, final concentrations of coexisting carbon sources and toluene were $100 \mu \mathrm{M}$. After 2-h incubation for T3-lux-E. coli and T7-lux-E. coli and 1-h incubation for SP6-lux-E. coli, the luminescence intensity of each biosensor was measured immediately. Toluene analogs (i.e., benzene, $o$-xylene, $p$-xylene, and $m$ xylene) and intermediates of toluene degradation (benzoate) were added to TMM to evaluate the effects on the bioluminescence emissions of the three recombinant $E$. coli strains. Based on their solubility, $o$-xylene, $p$-xylene, and $m$-xylene were predissolved in $95 \%$ ethanol and added to TMM. The final concentrations of the toluene analogs, benzoate, and toluene in medium were $50-250,50-300$, and $100 \mu \mathrm{M}$, respectively. The cells were incubated for $2 \mathrm{~h}$ (T3-lux-E. coli and T7-lux-E. coli) or $1 \mathrm{~h}\left(\mathrm{SP} 6-\operatorname{lu} x-E\right.$. coli) at $37^{\circ} \mathrm{C}$; the luminescence intensity (in RLU) of these biosensors was then measured, as described above. Measurements were obtained from at least three independent experiments, each performed at least in triplicate.

\section{Establishment of calibration curve and measurement of real water sample}

To establish the relationships between the toluene concentration and the luminescence intensity of the three recombinant $E$. coli biosensors, we mixed $100 \mu \mathrm{L}$ of toluene (0.01-500 $\mu \mathrm{M}), 50 \mu \mathrm{L}$ of $4 \times$ TMM (without toluene), and $50 \mu \mathrm{L}$ of recombinant luminescent $E$. coli cells (final concentration after mixing: $5 \times 10^{7} \mathrm{cfu} / \mathrm{mL}$ ). We then operated at the optimal incubation time and conditions determined in previous experiments. Standard curves (known as calibration curves) were plotted from the linear regression of average luminescence intensity at each toluene concentration. To obtain the LOD concentration, we calculated the SD from the average of the three blank measurements, multiplied the SD by 3 , and then used the standard curve to determine the LOD concentration. To ensure that the established curves and methods were valid, we prepared similar solutions as mentioned above, but used groundwater (from Lin-Yuan Industrial Park, Kaohsiung City, Taiwan) and river water (from Tamsui River, New Taipei City, Taiwan) instead of pure toluene. The toluene concentration in the prepared solution was separately measured using the established GC-mass spectrometry (MS) method [41] as well as using our three recombinant $E$. coli biosensors. Considering practical application, the retention of illuminance of recombinant $E$. coli after its cryogenic storage is essential for biosensor usage; thus, similar experiments were conducted when the biosensors were cryogenically stored for 3 months. Data were obtained from at least three independent experiments, with each performed at least in triplicate.

\section{Acknowledgments \\ The authors thank J.T. Kuo and Y.J. Liao for help with partially analytical measurements. \\ Authors' contributions \\ All authors collaborated to carry out the work presented here. \\ Conceptualization, Guey-Horng Wang and Ying-Chien Chung; Formal ana- Iysis, Chun-Chi Kui and Chiu-Yu Cheng; Funding acquisition, Ying-Chien Chung; Investigation, Teh-hua Tsai, Chun-Chi Kui and Tzu-Ling Huang; Writ ing - original draft, Ying-Chien Chung; Writing - review \& editing, Guey- Horng Wang, Teh-hua Tsai and Ying-Chien Chung All authors read and ap- proved the manuscript.}

\section{Funding}

This research was supported by NSC 99-2815-C-157-005-E and MOST 1092313-B-157-001.

\section{Availability of data and materials}

All data generated or analyzed during this study are included in this published article.

Ethics approval and consent to participate

Not applicable.

Consent for publication

Not applicable.

Competing interests

The authors declare that they have no competing interests.

\section{Author details}

${ }^{1}$ Research Center of Natural Cosmeceuticals Engineering, Xiamen Medical College, Xiamen 361008, China. ${ }^{2}$ Department of Chemical Engineering and Biotechnology, National Taipei University of Technology, Taipei, Taiwan. ${ }^{3}$ Department of Biological Science and Technology, China University of Science and Technology, Taipei 11581, Taiwan.

Received: 25 April 2020 Accepted: 29 December 2020

Published online: 06 January 2021

\section{References}

1. Barberes GA, dos Reis RP, Spigolon ALD, Fonseca PE, de Mello CB, Barata MT. Groundwater natural contamination by toluene in Beja and Faro districts. Portugal Geosciences. 2018;8:9

2. Wang X, Bartha R. Effects of bioremediation on toxicity, mutagenesis, and microbiota in hydrocarbon-contaminated soils. In Remediation of Hazardous Waste Contaminated Soils, Wise, D.L.; Trantolo, D.J., Eds; Marcel Dekker; New York, USA, 1998, pp. 175-197.

3. EPA in Taiwan. Groundwater Pollution Control Standards. 2013. https://law. moj.gov.tw/ENG/LawClass/LawAll.aspx?pcode=00110006. Accessed 15 Mar 2020 . 
4. EPA in Taiwan. Drinking Water Quality Standards. 2017. https://law.moj.gov tw/ENG/LawClass/LawAll.aspx?pcode=00040019. Accessed 20 Feb 2020.

5. Namieśnik J. Trends in environmental analytics and monitoring. Crit Rev Anal Chem. 2000;30:221-69.

6. Kuncová G, Ishizaki T, Solovyev A, Trögl J, Ripp S. The repetitive detection of toluene with bioluminescence bioreporter Pseudomonas putida TVA8 encapsulated in silica hydrogel on an optical fiber. Materials. 2016;9:467.

7. Rodriguez-Mozaz S, de Alda MJL, Barceló D. Biosensors as useful tools for environmental analysis and monitoring. Anal Bioanal Chem. 2006;386:102541.

8. Xu TT, Close DM, Sayler GS, Ripp S. Genetically modified whole-cell bioreporters for environmental assessment. Ecol Indic. 2013;28:125-41.

9. Hashemi GN, Mirzaei H, Sahebkar A, Poursadeghiyan M, Malekshahi ZV MA, Negahdari B. Biosensors for the detection of environmental and urban pollutions. J Cell Biochem. 2018;119:207-12.

10. Cheng CY, Kuo JT, Lin YC, Liao YR, Chung YC. Comparisons of Vibrio fischeri, Photobacterium phosphoreum, and recombinant luminescent using Escherichia coli as BOD measurement. J Environ Sci Health A. 2010:45:233-8.

11. Gui Q, Lawson T, Shan S, Yan L, Liu Y. The application of whole cell-based biosensors for use in environmental analysis and in medical diagnostics. Sensors. 2017;17:1623.

12. Kong IC. Effects of binary mixtures of inducers (toluene analogs) and of metals on bioluminescence induction of a recombinant bioreporter strain. Sensors. 2014;14:18993-9006.

13. Ray S, Panjikar S, Anand R. Design of protein-based biosensors for selective detection of benzene groups of pollutants. ACS Sens. 2018;3:1632-8.

14. Burlage RS. Emerging technologies: Bioreporters, biosensors, and microprobes. In: Hurst CJ, editor. Manual of Environmental Microbiology. 2nd ed. Washington, DC: ASM; 2002. p. 147-57.

15. Zhou Y, Fang Y, Ramasamy RP. Non-covalent functionalization of carbon nanotubes for electrochemical biosensor development. Sensors. 2019;19: 392.

16. Kim MN, Park HH, Lim WK, Shin HJ. Construction and comparison of Escherichia coli whole-cell biosensors capable of detecting aromatic compounds. J Microbiol Methods. 2005;60:235-45.

17. Burlage RS, Tillmann J. Biosensors of bacterial cells. J Microbiol Methods. 2017;138:2-11.

18. Axelrod T, Eltzov E, Marks RS. Bioluminescent bioreporter pad biosensor for monitoring water toxicity. Talanta. 2016;149:290-7.

19. Nakamura $\mathrm{H}$. Current status of water environment and their microbial biosensor techniques-part II: recent trends in microbial biosensor development. Anal Bioanal Chem. 2018;410:3967-89.

20. Willardson BM, Wilkins JF, Rand TA, Schupp JM, Hill KK, Keim P, Jackson PJ. Development and testing of a bacterial biosensor for toluene-based environmental contaminants. Appl Environ Microbiol. 1998;64:1006-12.

21. Li YF, Li FY, Ho CL, Liao VHC. Construction and comparison of fluorescence and bioluminescence bacterial biosensors for the detection of bioavailable toluene and related compounds. Environ Pollut. 2008;152:123-9.

22. Zeinoddini M, Khajeh K, Behzadian F, Hosseinkhani S, Saeedinia AR, Barjesteh $\mathrm{H}$. Design and characterization of an aequorin-based bacterial biosensor for detection of toluene and related compounds. Photochem Photobiol. 2010;86:1071-5.

23. Akbar M, Narayanan S, Restaino M, Agah M. A purge and trap integrated microGC platform for chemical identification in aqueous samples. Analyst. 2014;139:3384-92.

24. Eun HM. RNA polymerases. In: Enzymology Primer for Recombinant DNA Technology. San Diego: Elsevier Science Publishing Co Inc; 1996. p. $491-$ 566.

25. Martin CT, Esposito EA, Theis K, Gong P. Structure and function in promoter escape by T7 RNA polymerase. Prog Nucleic Acid Res Mol Biol. 2005;80:32347.

26. Zhu LP, Li ZF, Sun X, Li SG, Li YZ. Characteristics and activity analysis of epothilone operon promoters from Sorangium cellulosum strains in Escherichia coli. Appl Microbiol Biotechnol. 2013;97:6857-66.

27. Dollard MA, Billard P. Whole-cell bacterial sensors for the monitoring of phosphate bioavailability. J Microbiol Methods. 2003;55:221-9.

28. de Las HA, de Lorenzo V. Engineering whole-cell biosensors with no antibiotic markers for monitoring aromatic compounds in the environment. Methods Mol Biol. 2012;834:261-81
29. Akkermans S, Logist F, Van Impe JF. An interaction model for the combined effect of temperature, $\mathrm{pH}$ and water activity on the growth rate of E. coli K12. Food Res Int. 2018;106:1123-31.

30. Blazeck J, Alper HS. Promoter engineering: recent advances in controlling transcription at the most fundamental level. Biotechnol J. 2013;8:46-58.

31. Marqués S, Gallegos MT, Manzanera M, Holtel A, Timmis KN, Ramos JL. Activation and repression of transcription at the double tandem divergent promoters for the $x y / R$ and $x y / S$ genes of the TOL plasmid of Pseudomonas putida. J Bacteriol. 1998;180:2889-94.

32. Gallegos MT, Marqués S, Ramos JL. Expression of the TOL plasmid xylS gene in Pseudomonas putida occurs from $\sigma^{70}$-dependent promoter or from alpha $\sigma^{70}$ - and $\sigma^{54}$-dependent tandem promoters according to the compound used for growth. J Bacteriol. 1996;178:2356-61.

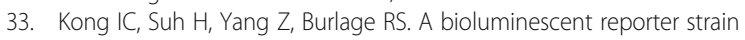
utilizing the lower pathway promoter (pm) of the $x y l$ operon of Pseudomonas: optimization of a bioassay for $m$-toluate. Adv Environ Res. 2004:8:647-54.

34. Ikuma K, Gunsch C. Effect of carbon source addition on toluene biodegradation by an Escherichia coli DH5a transconjugant harboring the TOL plasmid. Biotechnol Bioeng. 2010;107:269-77.

35. Martínez-Lavanchy PM, Müller C, Nijenhuis I, Kappelmeyer U, Buffing M, McPherson K, Heipieper HJ. High stability and fast recovery of expression of the TOL plasmid-carried toluene catabolism genes of Pseudomonas putida mt-2 under conditions of oxygen limitation and oscillation. Appl Environ Microbiol. 2010;76:6715-23.

36. Espinosa-Urgel M, Serrano L, Ramos JL, Ferna'ndez-Escamilla AM. Engineering biological approaches for detection of toxic compounds: a new microbial biosensor based on the Pseudomonas putida TtgR Repressor Mo Biotechnol 2015;57:558-564.

37. Casavant NC, Thompson D, Beattie GA, Phillips GJ, Halverson LJ. Use of a site-specific recombination-based biosensor for detecting bioavailable toluene and related compounds on roots. Environ Microbiol. 2003;5:238-49.

38. Zhong Z, Fritzsche M, Pieper SB, Wood TK, Lear KL, Dandy DS, Reardon KF. Fiber optic monooxygenase biosensor for toluene concentration measurement in aqueous samples. Biosens Bioelectron. 2011;26:2407-12.

39. Stiner $L$, Halverson LJ. Development and characterization of a green fluorescent protein-based bacterial biosensor for bioavailable toluene and related compounds. Appl Environ Microbiol. 2002;68:1962-71.

40. Abu-Ali $\mathrm{H}$, Nabok A, Smith TJ. Electrochemical inhibition bacterial sensor array for detection of water pollutants: artificial neural network (ANN) approach. Anal Bioanal Chem. 2019:411:7659-68.

41. USEPA Method 624.1: Purgeables by GC/MS., 2016.

\section{Publisher's Note}

Springer Nature remains neutral with regard to jurisdictional claims in published maps and institutional affiliations.

\section{Ready to submit your research? Choose BMC and benefit from:}

- fast, convenient online submission

- thorough peer review by experienced researchers in your field

- rapid publication on acceptance

- support for research data, including large and complex data types

- gold Open Access which fosters wider collaboration and increased citations

- maximum visibility for your research: over 100M website views per year

At $\mathrm{BMC}$, research is always in progress.

Learn more biomedcentral.com/submissions 